\title{
Effect of Weather Parameters on Population Dynamics of Paddy Pests
}

\author{
G. Madhuri*, P.C. Dash and K.K. Rout \\ Department of Entomology, College of Agriculture, Orissa University of \\ Agriculture and Technology, Bhubaneswar, India \\ *Corresponding author
}

\begin{tabular}{|c|c|}
\hline & A B S T R A C T \\
\hline Keywords & \multirow{4}{*}{$\begin{array}{l}\text { The field experiment was conducted at Central Research Farm of Orissa } \\
\text { University of Agriculture and Technology, Bhubaneswar during summer } 2014-15 \\
\text { and kharif- } 2015 \text { to study the effect of weather parameters on population dynamics } \\
\text { of paddy pests with twelve treatments and four replications in sub plot size of } 15 \mathrm{~m} \\
\text { x } 10 \mathrm{~m} \text { taking Lalat and Swarna as test cultivar during summer } 2014-15 \text { and kharif } \\
-2015 \text { following the recommended package of practices. Temperature and relative } \\
\text { humidity favours stem borer, leaf folder, whorl maggot and green leaf hopper, } \\
\text { brown plant hopper and white backed plant hopper, but relative humidity was not } \\
\text { ideal for leaf folder and whorl maggot. Rainfall discourages stem borer, leaf } \\
\text { folder, whorl maggot and green leaf hopper but encourage brown plant hopper and } \\
\text { white backed plant hopper. }\end{array}$} \\
\hline $\begin{array}{l}\text { Paddy, Weather } \\
\text { parameters, } \\
\text { Population } \\
\text { dynamics, Pest. }\end{array}$ & \\
\hline Article Info & \\
\hline $\begin{array}{l}\text { Accepted: } \\
\text { 17 September } 2017 \\
\text { Available Online: } \\
10 \text { October } 2017\end{array}$ & \\
\hline
\end{tabular}

\section{Introduction}

Rice (Oryza sativa L.) is an important staple food crop for more than half of the world population and accounts for more than $50 \%$ of the daily calorie intake (Khush, 2005). Rice is grown in many regions across India. It thrives well under varying ecosystems starting from rain fed upland (dry systems) to rain fed lowland (wet system) and the deep water situations. In India, rice occupies one-quarter of the total cropped area, contributes about 40 to $43 \%$ of total food grain production and continues to play a vital role in the national food and livelihood security system. India is world's second largest rice producer and consumer next to China. Total area under rice in India is 43.95 million hectare with annual production of 106.54 million tonnes.
In Odisha, rice is also the staple food of almost entire population and is grown on an area about 4.18 million hectare with a production about 7.58 million tonnes. Odisha contributes about $7.12 \%$ of national production of rice (Directorate of Economics and Statistics, Department of Agriculture and Cooperation, 2014).

The seasonal effects of weather and ongoing changes in climatic conditions will directly lead to modifications in dispersal and development of insect species. The changes in surrounding temperature regimes certainly involve alterations in development rates, voltinism and survival of insects and subsequently act upon size, density and 
genetic composition of populations, as well as on the extent of host plant exploitation (Bale et al., 2002). The developmental success of insect herbivores also indirectly depends on climate, as environmental parameters impact on plant physiology. Insects and plants are exposed to complex interactions among changes in temperature, precipitation and, increased levels of $\mathrm{CO}$ and variations in nutrient availability.

\section{Materials and Methods}

The field experiments were laid out during summer 2014-15 and kharif 2015 Randomized block design (RBD) with twelve treatments and four replications at Central Farm, OUAT, Bhubaneswar to assess the effect of weather parameters on population dynamics of paddy pests. The soil of the experimental plot was lateritic sandy loam.

The seedlings of rice variety Lalat and Swarna was taken as the test cultivar in summer 2014-15 and Kharif-2015 were planted in plots of size $15 \mathrm{~m} \times 10 \mathrm{~m}$ at spacing of $20 \mathrm{~cm} \times 10 \mathrm{~cm}$ with recommended agronomic practices.

The detailed meteorological data of the locality during the experimental periods have been presented below in figure 1 .

\section{Statistical analysis}

Correlation analysis is drawn between data recorded on pest population and weather parameters. Based on this statistical analyzed data, the results of the investigation have been interpreted and conclusions have been drawn.

\section{Results and Discussion}

Correlation study conducted on weather parameters with major pest of rice during summer 2014-15 and kahrif- 2015 at
Bhubaneswar. The data presented in Table 1 on the incidence of yellow stem borer (YSB) damage (\%) during summer 2014-2015 was positively correlated with maximum temperature (0.68), minimum temperature (0.71), relative humidity at evening (0.94) and negatively correlated with rainfall $(-0.05)$ and bright sun shine (-0.86). Similar trend was observed during kharif- 2015, whereas it was positively correlated with maximum temperature (1.63), minimum temperature (0.98), relative humidity at morning (0.45), relative humidity at evening (0.84) and negatively correlated with rainfall $(-0.56)$ and bright sun shine (-0.69) during kharif 2015. Similar results have been reported by Adiroubane et al., (2007) in paddy.

The incidence of leaf folder leaf damage (\%) during summer 2014-15 was positively correlated with maximum temperature $(0.18)$, minimum temperature $(0.84)$, relative humidity at evening (0.58) and bright sun shine (0.33) whereas negatively correlated with relative humidity at evening (0.58) and rainfall (-0.57). During kharif- 2015 leaf folder leaf damage (\%) was positively correlated with maximum temperature $(0.70)$, minimum temperature (0.69) and bright sun shine (0.74) and negatively correlated with relative humidity at morning (-0.62), relative humidity at evening (-0.71) and rainfall $(-0.94)$. The incidence of whorl maggot leaf damage (\%) during summer 2014-15 was positively correlated with maximum temperature (0.99), minimum temperature (0.98), relative humidity at morning (0.81), relative humidity at evening (0.97) and rainfall (0.77). Whereas bright sun shine $(-0.10)$ was negatively correlated.

During kharif-2015 the leaf damage (\%) by whorl maggot was positively correlated with maximum temperature (0.98), relative humidity at evening (0.02) and negatively correlated with minimum temperature $(-0.37)$, 
relative humidity at morning (-0.88), rainfall $(-0.24)$ and bright sun shine (-0.41). During kharif -2015 the mixed population of BPH and WBPH (no/hill) was positively correlated with maximum (0.30) and minimum temperature (0.39), relative humidity at morning (0.34), rainfall (0.42) and bright sun shine (0.08) whereas negatively correlated with relative humidity at evening (-0.78). During kharif -2015, the GLH (no/hill) was positively correlated with maximum temperature (0.12), minimum temperature $(0.92)$ and bright sun shine (0.05). Whereas, negatively correlated with relative humidity at morning (-0.44), relative humidity at evening $(-0.42)$, and rainfall $(-0.77)$.

Table.1 Correlation of weather parameters with major pests of rice during summer 2014-15 and kharif 2015 at Bhubaneswar

\begin{tabular}{|l|l|l|l|l|l|l|l|l|}
\hline \multirow{2}{*}{ Weather parameters } & \multicolumn{2}{l}{$\begin{array}{l}\text { Yellow Stem borer } \\
(\%)\end{array}$} & \multicolumn{2}{l|}{ Leaf folder (\%) } & \multicolumn{2}{l|}{ Whorl maggot (\%) } & $\begin{array}{l}\text { BPH \& WBPH } \\
\text { (No/hill) }\end{array}$ & GLH (No/ hill) \\
\cline { 2 - 10 } & Summer & Kharif & Summer & Kharif & Summer & Kharif & Kharif & Kharif \\
\hline Max. temperature ${ }^{\circ} \mathrm{C}$ & 0.68 & 1.63 & 0.18 & 0.70 & 0.99 & 0.98 & 0.30 & 0.12 \\
\hline Min. temperature ${ }^{\circ} \mathrm{C}$ & 0.71 & 0.98 & 0.84 & 0.69 & 0.98 & -0.37 & 0.39 & 0.92 \\
\hline RH at morning & 0.01 & 0.45 & -0.37 & -0.62 & 0.81 & -0.88 & 0.34 & 0.44 \\
\hline RH at evening & 0.94 & 0.84 & 0.58 & -0.71 & 0.97 & 0.02 & -0.78 & -0.42 \\
\hline Rainfall (mm) & -0.05 & -0.56 & -0.57 & -0.94 & 0.77 & -0.24 & 0.42 & -0.77 \\
\hline $\begin{array}{l}\text { Bright sun shine } \\
\text { (hours) }\end{array}$ & -0.86 & -0.69 & 0.33 & 0.74 & -0.10 & -0.41 & 0.08 & 0.05 \\
\end{tabular}

Fig.1 Meteorological variables during the crop growth period 2014- 2015

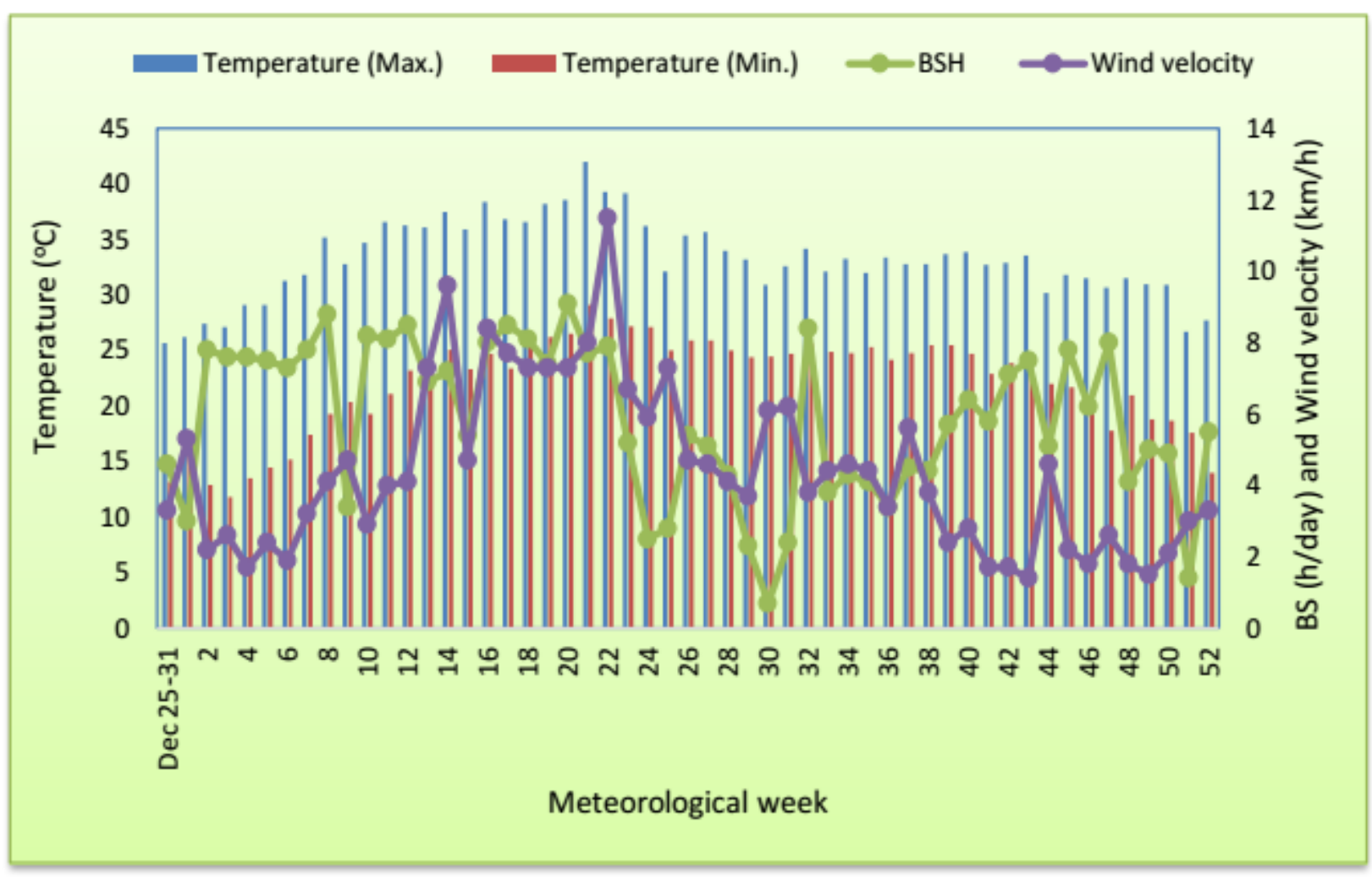




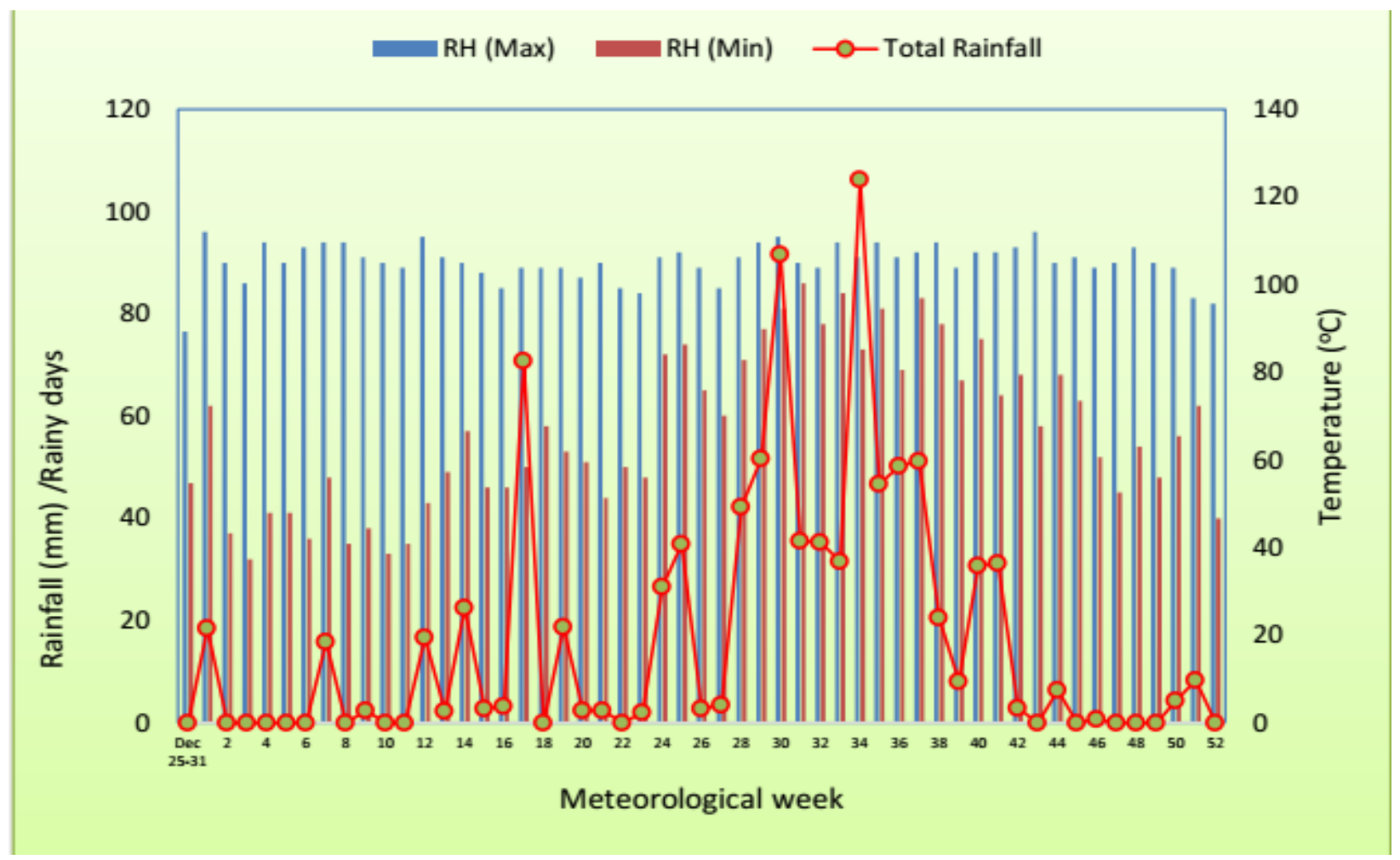

Adiroubane et al., (2007) concluded that high stem borer incidence during months of March $\left(27.6^{\circ} \mathrm{c}\right)$ August- September $\left(30.1^{\circ} \mathrm{C}\right)$ and October- November $\left(21^{\circ} \mathrm{C}\right)$. Stem borer incidence at relative humidity per cent ranged between 95.9 to $65.7,82.2$ to 54.5 and 95.3 to 82.8 respectively. Karuppaiah et al., (2012) reported that abiotic parameters are having direct impact on insect population dynamics through modulation of developmental rates, survival, fecundity, voltinism and dispersal and revealed that, declined survival rate of brown plant hopper Nilaparvatha lugens (Stal) and rice leaf folder, Cnaphalocrocis medinalis (Guen) at higher temperature. Kakde et al., (2014) reported yellow stem borer infestation reached its peak during first week of September $(5.58 \% \mathrm{DH})$ and 1 st week of October (5.79\% WEH). Kalita et al., (2015) observed that the whorl maggot started the infestation at initial stage of the crop and damaged maximum (22.25- 24.25 damaged leaves/10 hills) in the second fortnight of July. Stem borer infestation was found maximum during August-September (6.82-
$7.62 \%$ dead heart). They also attacked the rice crop at reproductive stage which resulted in white ear head. The maximum white ear head $\%$ was recorded in second fortnight of October. The leaf folder population was found maximum in the last part of August and first part of September $(14.50$ - 16.75 damaged leaves/10 hills).Thus, the present findings derived support from the finding of above workers.

The studies on correlation of weather parameters produced the fact that temperature and relative humidity favoured stem borer, leaf folder, whorl maggot and green leaf hopper, brown plant hopper and white backed plant hopper but relative humidity was unfavourable for leaf folder and whorl maggot. Rainfalls discourage stem borer, leaf folder, whorl maggot and green leaf hopper but encourage brown plant hopper and white backed plant hopper. Treatments (T5, T6, and T7) had recorded lower stem borer incidence and produced higher grain yield. 


\section{References}

Adiroubane, D., and Raja K. 2007. Influence of Weather Parameters on the Occurrence of Rice Yellow Stem Borer, Scirpophaga incertulus (Walker). Journal of Rice Research, 3(1): 22- 25.

Bale, J., Masters G, Hodkinson I, Awmack C, Inbezemer TM, Brown VK, Butterfield, Buse, A, Coulson JC, Farrar J, Good GJ, Harrington R, Hartley S, Jones TH, Lindroth L, Press M, Mrnioudis I, Watt A and Whittaker A. 2002. Herbivore in global climate change research: direct effects of rising temperature on insect herbivores. Journal Global Change Biology, 8(5): 1-16.
Kakde, A.M., and Patel KG. 2014. Seasonal incidence of rice yellow stem borer (Scirpophaga Incertulas Wlk.) in relation to conventional and Sri Methods of planting and its correlation with weather parameters. Journal of Agriculture and Veterinary Science. 7(6): 05-10.

Kalita, H., Avasthe RK, Ramesh K. 2015. Effect of weather parameters on population buildup of different insect pests of rice and their natural enemies. Indian Journal of Hill Farming. 28(1): 69-72.

Khush, G.S., 2005. What it will take to feed five billion rice consumers by 2030 . Plant Molecular Biology, 59: 1-6.

\section{How to cite this article:}

Madhuri, G., P.C. Dash and Rout, K.K. 2017. Effect of Weather Parameters on Population Dynamics of Paddy Pests. Int.J.Curr.Microbiol.App.Sci. 6(10): 2049-2053.

doi: https://doi.org/10.20546/ijcmas.2017.610.243 